\title{
TARTU RADIOCARBON DATES VIII
}

\section{E ILVES}

Institute of Zoology and Botany, Academy of Sciences, Estonian SSR

The present list includes 66 dates of geologic samples determined using the liquid-scintillation ${ }^{11} \mathrm{C}$ metod at the Geobiochemical Laboratory of the Institute of Zoology and Botany, Academy of Sciences, Estonian SSR. Benzene synthesized from wood dating from $1850 \pm 10 \mathrm{yr}$ served as a reference standard. All radiocarbon dates have been calculated using $5568 \pm 30 \mathrm{yr}$ before $\mathrm{AD} 1950$ as the half-life of ${ }^{14} \mathrm{C}$.

\section{Senno Bog series}

Senno bog lies in Pskov region, $5 \mathrm{~km}$ SW of Izborsk RR Sta. Sample coll 1970 by E Ilves, A Sarv, and T Rinne; pollen analyses by A Sarv.

TA-460. Senno

Sphagnum peat from depth 60 to $70 \mathrm{~cm}$. Pollen Zone SA2.

TA-454. Senno

Phragmites peat from depth 90 to $100 \mathrm{~cm}$. Boundary of Pollen Zones SAl and SA2.

TA-455. Senno

Phragmites peat from depth 160 to $170 \mathrm{~cm}$. Sub-Boreal and SubAtlantic contact.

TA-456. Senno

Phragmites peat with admixture of lake lime from depth 190 to $200 \mathrm{~cm}$. Transition from lake stage to swamp.

TA-461. Senno Zone AT2.

Lake lime with mollusk shells from depth 200 to $210 \mathrm{~cm}$. Pollen

TA-457. Senno

$6660 \pm 90$

Lake lime with mollusk shells from depth 250 to $260 \mathrm{~cm}$. BorealAtlantic contact.

TA-519. Senno

Lake lime with mollusk shells from depth 260 to $270 \mathrm{~cm}$. Boundary of Pollen Zones BO2 and BO1. Empirical boundary of spruce pollen, rational boundary of alder and broad-leaved tree pollen.

TA-458. Senno

Sapropel with admixture of lake lime from depth 280 to $290 \mathrm{~cm}$. PreBoreal and Boreal contact. 
TA-459. Senno

Sapropel with plant remains (reed) and with admixture of sand from depth 290 to $300 \mathrm{~cm}$. Dryas and Pre-Boreal contact.

\section{Mốksi Bog series}

Mõksi bog lies $3 \mathrm{~km}$ SW of Kilingi-Nõmme, in SW of Estonian SSR. Sample coll 1970 by E Ilves, A Sarv and T Rinne. Pollen analyses by A Sarv, botanic determination by M Ilomets (Sarv \& Ilves, 1976).

TA-404. Mõksi

Sphagnum peat from depth 170 to $180 \mathrm{~cm}$. Boundary of Pollen Zones SAl and SA2.

TA-405. Mõksi

Sphagnum peat from depth 320 to $330 \mathrm{~cm}$. Sub-Boreal and SubAtlantic contact.

TA-406. Mõksi

$2990 \pm 60$

Sphagnum peat from depth 390 to $400 \mathrm{~cm}$. Pollen Zone SB2. Culmination of spruce pollen.

TA-407. Mõksi

$4220 \pm 60$

Sphagnum peat from depth 450 to $460 \mathrm{~cm}$. Pollen Zone SB1.

TA-408. Mõksi

$6100 \pm 70$

Peat-like sapropel from depth 570 to $580 \mathrm{~cm}$. Pollen Zone AT2. Rational boundary of spruce pollen.

TA-409. Mõksi

$8160 \pm 80$ and $\mathrm{BO} 2$.

Sapropel from depth 630 to $640 \mathrm{~cm}$. Boundary of Pollen Zones BO1

\section{Kõivasoo Bog series}

Kõivasoo bog is in S of Kõpu peninsula, Hiiumaa Dist, Estonian SSR. Thickness of peat $1.8 \mathrm{~m}$, thickness of lake sediments is $1.2 \mathrm{~m}$. Sample coll 1972 by E Ilves and A Sarv. Pollen analyses by A Sarv, diatomic analyses by M Pork.

TA-523. Kõivasoo

$1060 \pm 60$

Sphagnum cuspidatum peat from depth 0 to $10 \mathrm{~cm}$.

TA-524. Kõivasoo

$$
2440 \pm 60
$$

Sphagnum peat of transition type from depth 50 to $60 \mathrm{~cm}$. Pollen Zone SB2, $10 \mathrm{~cm}$ above Sub-Boreal and Sub-Atlantic contact.

\section{TA-525. Kõivasoo}

$4360 \pm 60$

Sphagnum peat of fen type from depth 100 to $110 \mathrm{~cm}$. Pollen Zone SB1. Rational boundary of spruce pollen. 
TA-526. Kõivasoo

$4860 \pm 70$

Sapropel from depth 180 to $190 \mathrm{~cm}$. Atlantic and Sub-Boreal contact. Empirical boundary of spruce pollen. Transition from lake stage to swamp.

TA-527. Kõivasoo

Detritus sapropel from depth 200 to $210 \mathrm{~cm}$. Boundary of Pollen Zones ATl and AT2.

\section{TA-528. Kõivasoo}

Lake lime from depth 220 to $230 \mathrm{~cm}$. Pollen Zone AT1. Empirical boundary of oak and linden pollen. End of lake lime sedimentation.

\section{TA-529. Kõivasoo}

$7850 \pm 70$

Lake lime from depth 230 to $240 \mathrm{~cm}$. Boreal and Atlantic contact.

TA-530. Kõivasoo

$81.90 \pm 90$

Lake lime from depth 270 to $280 \mathrm{~cm}$. Boundary of Pollen Zones $\mathrm{BO} 2$ and BO1. Rational boundary of alder and elm pollen.

\section{Nigula Bog series}

Nigula bog lies at SW border of coastal region of Estonian SSR, $35 \mathrm{~km} \mathrm{~S}$ of Pärnu and $10 \mathrm{~km} \mathrm{E}$ of coast of Riga Bay. Bog stretches in N-S direction with length ca $9 \mathrm{~km}$ and width 3 to $4 \mathrm{~km}$. W from longitudinal axis of bog rise 5 islets covered with wood flora. In general, mire sites of raised bog type are characteristic of this bog. Sample coll 1973 by E Ilves and A Sarv from E (Nigula 1) and W (Nigula 2) parts of mire complex. Pollen analysis by A Sarv, botanic determination by M Ilomets (Sarv \& Ilves, 1976).

\section{TA-562. Nigula 1}

$1240 \pm 60$

Complex emerged peat from depth 100 to $110 \mathrm{~cm}$. Pollen Zone SA2.

TA-790. Nigula 1

$2150 \pm 70$

Complex emerged peat and Sphagnum cuspidatum peat from depth 160 to $170 \mathrm{~cm}$. Pollen Zone SA1.

TA-555. Nigula 1

$2820 \pm 70$

Sphagnum and Eriophorum vaginatum peat from depth 220 to $230 \mathrm{~cm}$. Sub-Boreal and Sub-Atlantic contact.

TA-556. Nigula 1

$3480 \pm 80$

Complex emerged peat from depth 280 to $290 \mathrm{~cm}$. Pollen Zone SB2.

TA-791. Nigula 1

$3900 \pm 70$

Complex emerged peat from depth 320 to $330 \mathrm{~cm}$. Pollen Zone SB1.

TA-557. Nigula 1

$3960 \pm 80$

Complex emerged peat from depth 340 to $350 \mathrm{~cm}$. Pollen Zone SB1. 
TA-558. Nigula 1 $4330 \pm 60$

Eriophorum-Scheuchzeria peat from depth 460 to $470 \mathrm{~cm}$. Pollen Zone SB1. Culmination of oak pollen.

TA-559. Nigula 1

$4720 \pm 80$ contact.

Sedge-forest peat from depth 470 to $480 \mathrm{~cm}$. Atlantic and Sub-Boreal

TA-566. Nigula 1

$6230 \pm 70$

Eriophorum and Phragmites peat (contact) from depth 510 to $520 \mathrm{~cm}$. Pollen Zone AT2. Culmination of elm pollen.

TA-560. Nigula 1

$\mathbf{7 0 4 0} \pm \mathbf{8 0}$

Phragmites peat from depth 520 to $530 \mathrm{~cm}$. Pollen Zone ATl. Rational boundary of linden pollen.

TA-561. Nigula 1

$7840 \pm 80$

Sapropel from depth 580 to $590 \mathrm{~cm}$. Boreal and Atlantic contact. Rational boundary of elm pollen.

TA-654. Nigula 2

$580 \pm 60$ SA3.

Woodland and wet pine peat from depth 50 to $60 \mathrm{~cm}$. Pollen Zone

TA-788. Nigula 2

$1100 \pm 60$

Sphagnum fuscum peat from depth 120 to $130 \mathrm{~cm}$. Boundary of Pollen Zones SA2 and SA3.

TA-655. Nigula 2

$1430 \pm 60$

Sphagnum fuscum peat from depth 160 to $170 \mathrm{~cm}$. Pollen Zone SA2. Culmination of spruce pollen.

TA-789. Nigula 2

$1420 \pm 60$

Sphagnum fuscum peat from depth 200 to $210 \mathrm{~cm}$. Pollen Zone SA2.

TA-656. Nigula 2

$2130 \pm 70$

Sphagnum fuscum peat from depth 240 to $250 \mathrm{~cm}$. Pollen Zone SA1.

TA-657. Nigula 2

$\mathbf{2 4 1 0} \pm \mathbf{7 0}$

Eriophorum with Sphagnum fuscum peat from depth 320 to $330 \mathrm{~cm}$. Pollen Zone SAl.

TA-658. Nigula 2

$2550 \pm 70$

Eriophorum with Sphagnum fuscum peat from depth 350 to $360 \mathrm{~cm}$. Pollen Zone SA1.

TA-659. Nigula 2

$2950 \pm 70$

Eriophorum with Sphagnum fuscum peat from depth 390 to $400 \mathrm{~cm}$. Pollen Zone SB2. Culmination of spruce pollen. 
TA-660. Nigula 2

$3670 \pm 70$

Sphagnum fuscum and Eriophorum peat (contact) from depth 430 to $440 \mathrm{~cm}$. Boundary of Pollen Zones SB1 and SB2.

TA-661. Nigula 2

$4870 \pm 70$ contact.

Eriophorum peat from depth 480 to $490 \mathrm{~cm}$. Atlantic and Sub-Boreal

TA-692. Nigula 2

$6190 \pm 80$

Eriophorum peat from depth 540 to $550 \mathrm{~cm}$. Pollen Zone AT2. Rational boundary of spruce.

TA-662. Nigula 2

$6320 \pm 80$

Eriophorum with Sphagnum fuscum peat from depth 570 to $580 \mathrm{~cm}$. Pollen Zone ATl. Culmination of elm pollen. Empirical boundary of spruce pollen.

TA-663. Nigula 2

$\mathbf{7 1 5 0} \pm \mathbf{8 0}$

Carex-Sphagnum peat from depth 640 to $650 \mathrm{~cm}$. Pollen Zone BO2. Rational boundary of alder pollen. Beginning of swamp formation.

TA-665. Nigula 2

$\mathbf{7 7 7 0} \pm \mathbf{8 0}$

Sapropel from depth 690 to $700 \mathrm{~cm}$. Pollen Zone BO2. Beginning of organic deposits.

\section{Zosu Bog series}

Zosu bog lies at $\mathrm{W}$ part of Luban plain, Latvian SSR, 5km E of Aickuja. Average thickness of organogenic deposits, 3m. Samples coll 1975 and subm by L Medne, botanic analyses by L Medne and A Guzlen, Latvian State Univ.

TA-881. Zosu

$1820 \pm 60$

Complex peat from depth 10 to $15 \mathrm{~cm}$. Pollen Zone SA2.

TA-880. Zosu

$2210 \pm 60$

Sphagnum medium peat from depth 30 to $35 \mathrm{~cm}$. Pollen Zone SA2.

TA-922. Zosu

$2470 \pm 70$

Sphagnum peat from depth 40 to $45 \mathrm{~cm}$. Boundary of Pollen Zones SA1 and SA2.

TA-921A. Zosu

$4160 \pm 70$

Forest mesotrophic peat from depth 60 to $65 \mathrm{~cm}$. Pollen Zone AT2.

TA-921B. Zosu

$4570 \pm 70$

Wood from depth 60 to $65 \mathrm{~cm}$.

TA-879. Zosu

$5620 \pm 70$

Forest mesotrophic peat from depth 85 to $90 \mathrm{~cm}$. Pollen Zone AT2. 
TA-897. Zosu

$6060 \pm 70$

Forest sedge peat from depth 100 to $105 \mathrm{~cm}$. Pollen Zone AT2.

TA-898. Zosu

$6560 \pm 80$

Forest sedge peat from depth 125 to $130 \mathrm{~cm}$. Boundary of Pollen Zones AT1 and AT2.

TA-899. Zosu

$7100 \pm 80$

Forest sedge peat from depth 145 to $150 \mathrm{~cm}$. Pollen Zone AT1.

TA-900. Zosu

$7450 \pm 70$

Forest sedge peat from depth 180 to $185 \mathrm{~cm}$. Boreal and Atlantic contact.

TA-923. Zosu

$\mathbf{7 7 0 0} \pm \mathbf{7 0}$

Forest sedge peat from depth 210 to $215 \mathrm{~cm}$. Boundary of Pollen Zones $\mathrm{BO} 1$ and $\mathrm{BO} 2$.

TA-878. Zosu

$8160 \pm 80$

Forest sedge peat from depth 220 to $225 \mathrm{~cm}$. Pollen Zone BO1. Boreal maximum of spruce pollen.

TA-877A. Zosu

$8550 \pm 80$

Forest sedge peat from depth 260 to $265 \mathrm{~cm}$. Pollen Zone BO1.

TA-877B. Zosu

$8700 \pm 80$

Repeat dating.

TA-876A. Zosu

$8400 \pm 80$

Forest sedge peat from depth 290 to $295 \mathrm{~cm}$. Pre-Boreal and Boreal contact.

TA-876B. Zosu

$8360 \pm 70$

Repeat dating.

TA-875. Zosu

Sapropel from depth 295 to $300 \mathrm{~cm}$.

$8020 \pm 80$

\section{RFFERFNCE}

Sarv, A A and Ilves, E O, 1976, Stratigraphy and geochronology of Holocene lake and mire deposits from the southwestern part of Estonia (in Russian), in: Palynology in continental and marine geological investigations: Riga, p 47-59. 